4. Бодрийяр, Ж. Прозрачность зла / Ж. Бодрийяр ; Пер. с фр. Л. Любарской, Е. Марковской. - 5-е изд. - М.: «Добросвет», «Издательство «КДУ»», 2014. - 260 с.

5. Шумпетер, Й. Капитализм, социализм и демократия / Й. Шумпетер - М: Эксмо, 2007. - 861 с.

6. Кругман П. Великая ложь / П. Кругман. - М. : АСТ, 2004. - 474 c.

7. Об утверждении Концепции национальной безопасности Республики Беларусь: Указ Президента Республики Беларусь от 9 ноября 2010 г. №575 // Комитет государственной безопасности Республики Беларусь. - Режим доступа: http://kgb.by/ru/ukaz575/. - Дата доступа: 02.09.2019.

УДК 330

\title{
HUMAN DEVELOPMENT AND REGIONAL GROWTH
}

Elkin S. E., candidate of economic sciences, docent

Elkina O. S., doctor of economic sciences, docent Russian Presidential Academy of National Economy and Public Administration North-West Institute of Management St Petersburg, Russia

Sustainable development indicators are called criteria and indicators used to measure the level of development of a particular geographic area (city, country, region, continent, the world community), to project its future state (economic, political, environmental, demographic, etc.), to determine the stability of this state. Indicators serve as a basis for planning the activity towards sustainable development, working out the policy in this area [1].

In the economic sphere sufficiently ambitious goals are determined:

- improvement of the territorial distribution of productive forces, economic zoning, building and strengthening of the regional economy points of growth;

- creating a positive image of the region as a region for prospective investments, with favorable conditions for doing business;

- development of foreign trade, interregional cooperation, implementation of the existing capacity in inter-territorial co-operation according to the strategic directions of the region and the neighboring regions development. 
It should be acknowledged that the achievement of most of these problems is not supported by the relevant management and material reserves. Hence, one more problem to be solved should be the need to develop indicators of sustainable development. In the works on sustainable development issues a systematic approach is used when complex structure is considered which includes social and ecological systems, social, economic and natural interaction. Given the task orientation (the terminology of control theory) the considered indicators are divided into three categories - indicators of the input, status indicators, performance management indicators.

The first characterize human activity, processes and characteristics that influence sustainable development.

The second illustrates the current status of the various aspects of sustainable development.

The third are response indicators that allow for political choice or any other way to respond to change the current state [2].

The main problem of sustainable development of regions is meaningful contradiction of interests of business and society, which is caused by the desire to obtain excessive profits in business in no time. The implementation of large-scale reforms in the Russian economy associated with the formation of a stable market economy, sustainable regional development and the transition to the path of socio-oriented technological development requires considerable investment and enhanced innovation processes at all hierarchical levels of government [4].

Most scientists believe that sustainable development of Russian regions can only be achieved by improving the efficiency of scientific and technical sphere. So, Gubaidulina T.N. and Orlova O.A. [3] point out that in the condition of shrinking natural resources, the growth of the economic system can be achieved only by increasing knowledge-based industries and services. Despite the excessive focus of scientists on the problems of regional development sustainability we have to agree with Bastrykin D.V. and Korenchuk A.A. [5] - the market is unable to consciously address the environmental and social costs of economic growth, as they are not obvious, delayed (lag effect), and generally do not fall on those who make decisions. Objectives and values of sustainable development differ from the market ones and are brought from the «outside». In general, it should be stated that the society has the right to set environmental and ethical boundaries to the expansion 
of the market system, not allowing for them to be determined by the market itself.

Multiple meanings and interpretations of the concept of «sustainable development» of the regions, its not being legally formalized, the diversity and heterogeneity of the indicators of development does not always lead to the correct understanding of the essence of the concepts and problems associated with it. Scientific concept of sustainability and sustainable development of the regional economy, as well as cities and administrative districts according to most researchers of the problem should include:

- indication that the origins of this quality are rooted in the objective existence of different proportions; it can be considered as a specific resource that has some potential properly reproduced, appearing and being used in special forms;

- identifying the sustainable economic development of the region as a specific object of management in a market economy model;

- criteria and indicators of sustainable development, and reasonable goals and objectives of management for different regions and types of taxonomy;

- generalized conclusions about promising practices in the stabilization activity of the federal government, the subjects of the Russian Federation, local government structures, as well as ways to optimize internal and external economic proportions [4].

Systematic study of the concept of sustainable economic development of the region can reveal the content of this quality (economic, social, institutional, etc.), as well as its capacity and ability to be best used.

\section{References}

1. Pokazateli ustojchivogo razvitija: struktura i metodologija. Per. s angl. Tjumen': Izd-vo IPOS SO RAN, 2000.

2. Morozov V.V. Optimizacija investirovanija tehnologicheskih innovacij kak osnova obespechenija ustojchivogo razvitija regiona // Vestnik UGTU-UPI, - 2003. - № 10.

3. Gubajdullina T.N., Orlova O.A. Osnovnye jelementy upravlenija ustojchivym razvitiem regiona na primere respubliki Tatarstan // Vestnik Kazanskogo gosudarstvennogo finansovo-jekonomicheskogo instituta, 2006. - № 3. - P. 69-72. 
4. Metelev S.E., Elkin S.E. Management of human development as a strategy for regional growth // North-East Academic Forum 2013, Harbin University of Commerce. - H. 1-4.

5. Bastrykin D.V., Korenchuk A.A. Ustojchivoe razvitie predprijatija kak faktor stabil'nogo razvitija regiona // Vestnik Tambovskogo universiteta. Serija: Gumanitarnye nauki, 2008. - № 5. - p. 140-144.

\section{УДК 330.111.4:330.341.1}

\section{ЭНЕРГИЯ КАК ДВИЖУЩАЯ СИЛА ИНДУСТРИАЛИЗАЦИИ}

Байнев В. Ф., Д.э.н., профессор, зав. каф. инноватики и предпринимательской деятельности

Рунков Ю. Ю., м.н.с. каф. инноватики

и предпринимательской деятельности Белорусский государственный университет

г. Минск, Республика Беларусь

Ретроспективный анализ достижений технико-технологического прогресса доказывает, что при всем их многообразии социальноэкономической миссией техники и технологий является трудосбережение - экономия рабочего времени и максимизация свободного времени общества. Рост производительности труда ведет к тому, что, с одной стороны, за то же самое время обществом продуцируется больше продукции и его благосостояние увеличивается. С другой стороны, прежний объем производства экономических благ может быть достигнут при меньших трудозатратах. Это обеспечивает обществу при том же уровне жизни больше свободного времени для развития, когда каждый может учиться и состояться как ученый, художник, спортсмен, семьянин и т.д. [1] Неслучайно, по словам выдающегося теоретика-политэконома К. Маркса, «экономия времени остается первым экономическим законом на основе коллективного производства» [2, с. 117].

Использование машин считается ключевым фактором роста производительности труда. При этом под машиной следует понимать механическое или электромеханическое устройство, преобразующее тот или иной вид природной энергии в полезную работу, связанную с трансформацией предметов труда в нужную людям 